\title{
Salvage radiotherapy for patients with PSA relapse after radical prostatectomy: a single institution experience Laurent Quero*1, Pierre Mongiat-Artus ${ }^{2}$, Vincent Ravery ${ }^{3}$, Claude Maylin ${ }^{1}$, François Desgrandchamps ${ }^{2}$ and Christophe Hennequin ${ }^{1}$
}

\author{
Address: ${ }^{1}$ Department of Radiation Oncology, Saint Louis Hospital, 1 avenue Claude Vellefaux, 75010 Paris, France, ${ }^{2}$ Department of Urology, \\ Saint Louis Hospital, 1 avenue Claude Vellefaux, 75010 Paris, France and ${ }^{3}$ Department of Urology, Bichat Hospital, 46 rue Henri-Huchard, 75018 \\ Paris, France \\ Email: Laurent Quero* - laurent.quero@wanadoo.fr; Pierre Mongiat-Artus - pierre.mongiat-artus@sls.aphp.fr; \\ Vincent Ravery - vincent.ravery@bch.aphp.fr; Claude Maylin - claude.maylin@sls.aphp.fr; \\ François Desgrandchamps - francois.desgrandchamps@sls.aphp.fr; Christophe Hennequin - christophe.hennequin@sls.aphp.fr \\ ${ }^{*}$ Corresponding author
}

Published: 29 January 2008

BMC Cancer 2008, 8:26 doi:10.1/86/147|-2407-8-26
Received: 22 October 2007

Accepted: 29 January 2008

This article is available from: http://www.biomedcentral.com/147I-2407/8/26

(C) 2008 Quero et al; licensee BioMed Central Ltd.

This is an Open Access article distributed under the terms of the Creative Commons Attribution License (http://creativecommons.org/licenses/by/2.0), which permits unrestricted use, distribution, and reproduction in any medium, provided the original work is properly cited.

\begin{abstract}
Background: To assess the efficacy of salvage radiotherapy (RT) for persistent or rising PSA after radical prostatectomy and to determine prognostic factors identifying patients who may benefit from salvage RT.

Methods: Between 1990 and 2003, 59 patients underwent RT for PSA recurrence after radical prostatectomy. Patients received a median of 66 Gy to the prostate bed with 3D or 2D RT. The main end point was biochemical failure after salvage RT, defined as an increase of the serum PSA value $>0.2 \mathrm{ng} / \mathrm{ml}$ confirmed by a second elevation.

Results: Median follow-up was 38 months. The 3-year and 5-year bDFS rates were $56.1 \%$ and $41.2 \%$ respectively. According to multivariate analysis, only preRT PSA $\geq 1 \mathrm{ng} / \mathrm{ml}$ was associated with biochemical relapse.
\end{abstract}

Conclusion: When delivered early, RT is an effective treatment after radical prostatectomy. Only preRT PSA $\geq \mathrm{I} \mathrm{ng} / \mathrm{ml}$ predicted relapse.

\section{Background}

In Europe, the estimated incidence of prostate cancer is 238,000 new cases with 85,000 deaths per year [1]. Radical prostatectomy is the most widely used treatment for localized prostate cancer. Unfortunately, local recurrences occur in up to one-third of the patients by 5 years after surgery. It is generally accepted that $30 \%(27-32 \%)$ of all patients by 10 years after surgery suffer biochemical relapse, defined as increasing serum prostate-specific antigen (PSA) levels $>0.2 \mathrm{ng} / \mathrm{ml}[2,3]$. PSA relapse exposes to a 34\% risk of metastatic disease at 5 years. After metastatic relapse, median survival is 5 years [4].

"Salvage" radiotherapy (RT) to the prostate bed for biochemical relapse achieved biochemical control in $10-66 \%$ of the patients at 5 years [5,6]. PSA failure after prostatectomy could reflect local relapse or metastatic disease. At present, modern imaging techniques lack the sensitivity to differentiate between these two types of relapse. Identification of the best candidates for RT should be 
based on factors predictive for local relapse. Numbers of positive margins, low Gleason score and/or long PSAdoubling time have been proposed to select patients for RT, but they are still discussed [7].

In this study, we evaluated RT efficacy and determine prognostic factors identifying patients who may benefit from salvage RT.

\section{Methods}

We reviewed the records of 59 patients who underwent RT between 1990 and 2003 for biochemical relapse of prostate cancer initially treated with radical prostatectomy. All patients had persistent or rising PSA $>0.20 \mathrm{ng} / \mathrm{ml}$ at some time after surgery. None had imaging (bone scan and/or abdominal-pelvic computed tomography (CT) Scan) or clinical evidence of metastases at the time of the biochemical relapse.

A number of potential predictive factors were recorded: initial PSA (before surgery); age at the time of the surgery; $\mathrm{T}$ stage; margin status ( 6 sides); seminal vesicle involvement or extracapsular invasion; surgical Gleason score; perineural invasion; PSA nadir after surgery; PSA-doubling time (PSA DT) between surgery and RT calculated as follows: Ln $2 \times(t 2-t 1) /[$ Ln (PSA t2) - Ln (PSA t1)] [8]; PSA before RT (preRT PSA) and interval between surgery and RT.

RT delivered to the prostate bed a median of 66 Gy in 2.2 Gy daily fractions, four days per week, with $18 \mathrm{MV}$ photon beams. Between 1990 and 1998, classical 2D RT was administered using a four-field box technique to 22 (37.3\%) patients with fields of $10 \mathrm{~cm} \times 10 \mathrm{~cm}$ shaped to protect small bowel, portions of the bladder and posterior rectal wall. The fields encompassed the prostatic/seminal vesicle bed and periprostatic tissues. Pelvic lymph nodes were not irradiated. After 1998, conformational 3D RT was adopted to define optimally the clinical target volume (CTV) and organs at risk (bladder and rectum). CTV included the prostatic/seminal bed, with a security margin to encompass subclinical disease in the periprostatic area. The planning target volume (PTV) was defined by extending the CTV $0.5 \mathrm{~cm}$ posteriorly and $1 \mathrm{~cm}$ in all other directions. No elective nodal irradiation was performed. Dose Volume Histograms were performed to decrease the dose at organs at risk. Treatment-related toxicity was graded according to the Radiation Therapy Oncology Group (RTOG) criteria [9] and the Expanded Prostate-cancer Index Composite (EPIC) score for urinary incontinence [10].

After radiation, patients were followed every 6 months by a radiation oncologist and a urologist with physical examination and PSA analysis. Imaging to exclude metastastic disease was performed at the physician's discretion, as was the prescription of hormone therapy for biochemical or clinical failure after RT. The interval between surgery and hormone therapy after RT failure was also recorded.

Biochemical failure after salvage RT was defined as an increase of the serum PSA value $>0.2 \mathrm{ng} / \mathrm{ml}$ confimed by a second elevation.

Clinical failure was defined as evidence of clinical, sonographic, radiographic, or scintigraphic recurrence. The primary end point was biochemical relapse or introduction of hormone therapy before the criteria of PSA recurrence or clinical failure before biochemical relapse were met.

The other end points were overall and specific survival rates.

\section{Statistical analysis}

Survival curves were plotted using the Kaplan-Meier method. Survival rates were calculated from the last day of RT. The date of failure was defined at the time of the biochemical failure.

Patients who biochemically had no evidence of disease (bNED) were censured at the time of last follow-up.

Univariate and multivariate analysis using a Cox proportional hazards regression analysis were conducted to identify significant predictors of biochemical outcome for several clinical and pathological factors: pre surgery PSA; Gleason score; high-grade histological differentiation (4 or 5); extra prostatic extension (capsule or seminal vesicle invasion); positive surgical margin(s); $\geq 3$ positive surgical margins; lymphovascular invasion; short PSA DT $\leq 12$ months; persistently high PSA after surgery $(>0.2 \mathrm{ng} / \mathrm{ml})$; preRT PSA $\geq 0.5, \geq 1$ or $\geq 2 \mathrm{ng} / \mathrm{ml}$; surgery-RT interval; duration of RT; classical 2D or 3D RT.

For all analyses, the level of significance was set at 0.05 .

Statistical analysis was performed using Statview software.

\section{Results}

\section{Patient characteristics}

Patient and tumor characteristics are reported in Table 1. Fifty-nine patients were treated within a 13 -year interval. It should be noted that $11(18.6 \%)$ patients had no lymph-node dissection at the time of radical prostatectomy and did not receive any lymph-node irradiation at the time of RT. One (2\%) patient had a nodal involvement at the time of RT. Seven patients $(12 \%)$ received short-term ( $\leq 6$ months) hormonetherapy, with Luteinizing Hormone Releasing Hormone agonist, after surgery, at the urologist's discretion. 
Table I: Characteristics of the $\mathbf{5 9}$ men who underwent RT for PSA relapse after radical prostatectomy

\begin{tabular}{ll}
\hline Characteristic patients, $\mathrm{n}$ & Values \\
\hline Age, median [range] & $62[46-76]$ years \\
Preoperative PSA, median [range] & $16.7[\mathrm{I}-60] \mathrm{ng} / \mathrm{ml}$ \\
PTNM stage, $\mathrm{n}(\%)$ & \\
PT2a & $2(3.4)$ \\
PT2b & $1(1.7)$ \\
PT2c & $22(37.3)$ \\
PT3a & $20(33.9)$ \\
PT3b & $14(23.7)$ \\
PN- & $47(79.7)$ \\
PN ${ }^{+}$ & $1(1.7)$ \\
PNx & $11(18.6)$ \\
Gleason score, $\mathrm{n}(\%)$ & \\
$3-6$ & $12(20.3)$ \\
$7 *$ & $30(50.9)$ \\
$3 * 4$ & $13(23.6)$ \\
$4+3$ & $13(23.6)$ \\
8 & $7(11.9)$ \\
9 & $10(16.9)$ \\
Positive surgical marginst, $\mathrm{n}(\%)$ & $35 / 58(60.3)$ \\
Minimal $<3$ & $19 / 34(55.9)$ \\
Extensive $\geq 3$ & $15 / 34(44.1)$ \\
Perineural invasion, $\mathrm{n}$ (\%) & $40 / 46(87)$ \\
Detectable PSA after surgery, $\mathrm{n}(\%)$ & $12(20.3)$ \\
PSA rise after postsurgical negativity, $\mathrm{n}(\%)$ & $47(79.7)$ \\
PSA doubling time, median & $12.9 \mathrm{months}$ \\
PSA nadir preRT, median & $0.4 \mathrm{ng} / \mathrm{ml}$ \\
PSA level preRT, median & $1.43 \mathrm{ng} / \mathrm{ml}$ \\
Surgery to RT interval, median & $26 \mathrm{months}$ \\
&
\end{tabular}

* Score composition not detailed for 4 patients.

Thirty-five patients had positive margins but no mention of margin status was made in one patient's report.

RT was delivered to $80 \%$ of the patients because of a rising PSA levels after postoperative negativity and for persistently high PSA after surgery for the remaining 20\%. 3D and 2D salvage RT was performed in $63 \%$ and $37 \%$ of the patients, respectively. The median RT dose delivered was 66 Gy (59.4-70.4) in a mean of 60 days.

\section{Survival and bDFS}

Median follow-up was 38 months after completing RT. At 3 years, the overall and specific survival rates were 93\% and $100 \%$ respectively. The estimated 5 -year overall survival rate was $87 \%$ and specific survival was $96 \%$.

bDFS at 3 years was 56.1\%. The estimated 5-year bDFS was $41.2 \%$ (Figure 1 ).

\section{Prognostic factors for bDFS}

Biochemical control was analyzed using different preRT PSA thresholds (from $<0.5$ to $\geq 2 \mathrm{ng} / \mathrm{ml}$ ) (Figure 2): patients with preRT PSA $<0.5$ or $[0.5-1] \mathrm{ng} / \mathrm{ml}$ had compa-

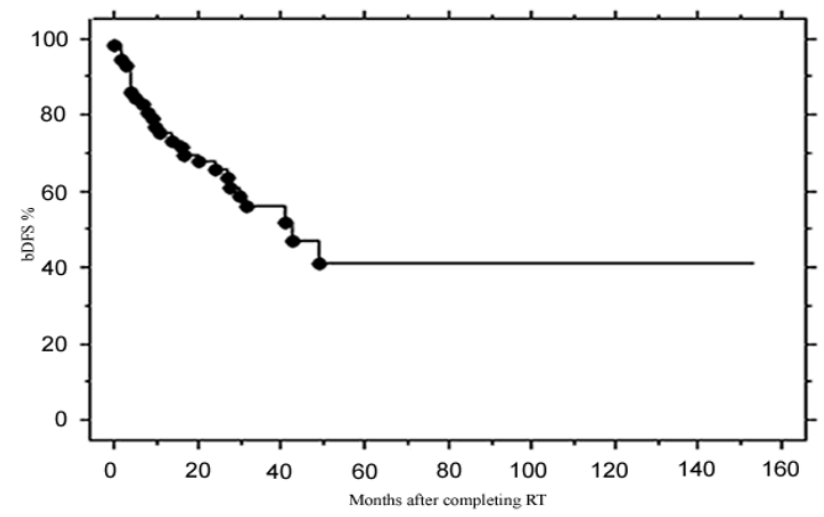

Figure I

bDFS after the end of RT according to PSA $>0.2 \mathrm{ng} / \mathrm{ml}$ definition.

rable bDFS rates $\approx 70 \%$ while those with PSA of [1-2] or $\geq 2 \mathrm{ng} / \mathrm{ml}$ had $\approx 30 \%$ bDFS at 3 years. The bDFS rates for these different PSA thresholds were significantly different $(\mathrm{p}=0.008)$. PreRT PSA of $1 \mathrm{ng} / \mathrm{ml}$ was the most significant threshold that could distinguish patients with good or bad biochemical control after RT: PSA $<1 \mathrm{ng} / \mathrm{ml}$ was associated with a 3 -year bDFS of $68.3 \%$ compared to $30.1 \%$ for $P S A \geq 1 \mathrm{ng} / \mathrm{ml}(\mathrm{p}=0.0006)$ (Figure 3$)$.

PreRT PSA $\geq 1(p=0.001)$ or $2 \mathrm{ng} / \mathrm{ml}(\mathrm{p}=0.04)$ and not Gleason score or margin status, in particular, were associated with poor 3-year bDFS outcome (Table 2). Multivariate analysis retained only preRT PSA $\geq 1 \mathrm{ng} / \mathrm{ml}$ as independently predictive of biochemical failure.

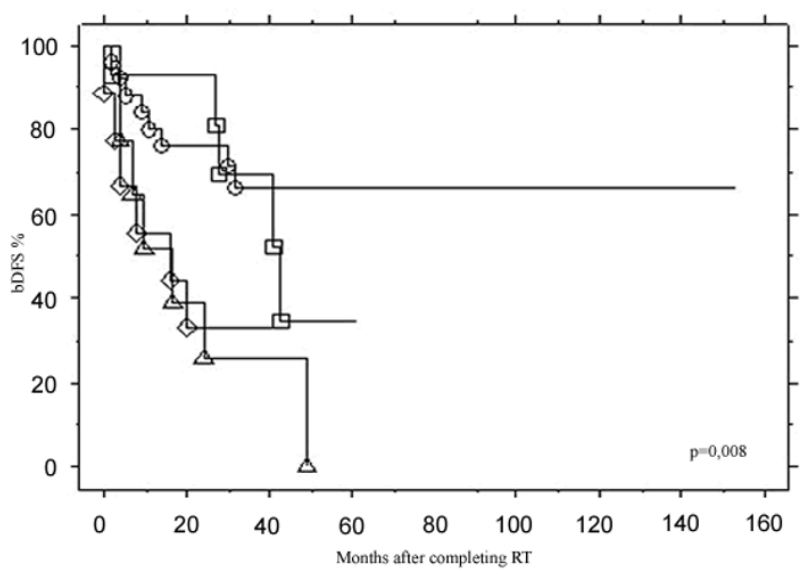

Figure 2

Comparisons of bDFS after the end of RT according to different preRT PSA thresholds. PSA $<0.5 \mathrm{ng} / \mathrm{ml}($ ) vs. [0.5-I] ng/ml( $\square)$ vs. [I-2] ng/ml( $\Delta)$ vs. $\geq 2 \mathrm{ng} / \mathrm{ml}(\diamond)$. 


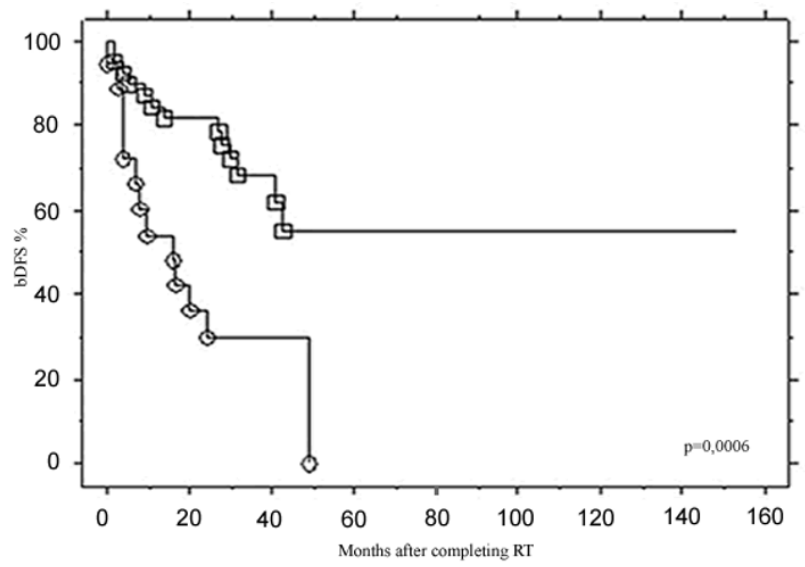

Figure 3

Comparison of bDFS after the end of RT according to I $\mathrm{ng} / \mathrm{ml}$ preRT PSA threshold. PSA $\geq \mathrm{I} \mathrm{ng} / \mathrm{ml}$ ( ) vs. $<$ I $\mathrm{ng} / \mathrm{ml}(\square)$.

\section{Treatment tolerance}

Late rectal toxicity (grade $\geq 2$ ) was seen in seven patients treated with 2D RT ( 2 grade 3 and 2 grade 4 ) versus 8 with 3D RT ( 1 grade 3 and 0 grade 4 ).

Severe (grade $\geq 2$ ) late urinary tract complications (stricture, hematuria) were observed in 3 patients who received 2D RT versus 1 given 3D RT, with 1 grade 3 and 0 grade 4
Table 2: Prognostic factors of bDFS after salvage RT at 3 years (PSA $>0.2 \mathrm{ng} / \mathrm{ml}$ definition), univariate analysis

\begin{tabular}{lccc}
\hline \multicolumn{1}{c}{ Criterion } & 3-year bDFS (\%) & \\
& Yes & No & P-value \\
\hline & & & \\
\hline Presurgical PSA $\geq 10$ & 58.2 & 48.2 & 0.8 \\
Gleason score $\geq 8$ & 40.3 & 65.2 & 0.2 \\
High grade $(\geq 4)$ & 52.2 & 87.5 & 0.3 \\
$\quad$ PT3 & 46.9 & 69.2 & 0.08 \\
PT3b & 41.7 & 60.7 & 0.2 \\
Positive margin(s) & 47.7 & 61.4 & 0.3 \\
$\geq 3$ positive margins & 58.3 & 58.8 & 0.7 \\
Perineural invasion & 48.3 & 83.3 & 0.8 \\
PSA DT $\leq 12$ months & 58.8 & 51.9 & 0.8 \\
No PSA negativity & 48.6 & 58.2 & 0.2 \\
PreRT PSA $\geq 2$ ng/ml & 33 & 60.9 & 0.04 \\
PreRT PSA $\geq 1$ ng/ml & 30.1 & 68.3 & 0.001 \\
Surgery-RT interval ( $\leq 12$ months) & 36.6 & 54.8 & 0.4 \\
RT duration ( $\geq 60$ days) & 54 & 57.5 & 1.0 \\
Classical 2D RT & 70 & 45.7 & 0.2 \\
& & &
\end{tabular}

PSA: Prostate specific antigen; DT: doubling time; RT: radiotherapy.

for each technique. Urinary incontinence (EPIC grade $\geq 2$ ) developed in 2 patients given 2D RT and 4 with 3D RT.

\section{Discussion}

We obtained a 3- and 5-year bDFS of $56.1 \%$ and $41.2 \%$ respectively, which are comparable to most of those previously reported for prostate cancer patients given RT after prostatectomy [11-31] (Table 3).

Table 3: Published series of salvage radiotherapy for biochemical failure after radical prostatectomy

\begin{tabular}{|c|c|c|c|c|}
\hline Investigator & Year of publication & Patients (n) & Median Follow-up (months) & Freedom from Biochemical Relapse \\
\hline Anscher [II] & 2000 & 89 & 48 & $50 \%$ at 4 years \\
\hline Peschel [I2] & 2000 & 39 & - & $27 \%$ at 3 years \\
\hline Pisansky [13] & 2000 & 166 & 52 & $46 \%$ at 5 years \\
\hline Catton [14] & 2001 & 59 & 44 & $48 \%$ at 3 years \\
\hline Koppie [15] & 2001 & 67 & 36 & $44 \%$ at 3 years \\
\hline Leventis [16] & 2001 & 49 & 29 & $43 \%$ at 3 years \\
\hline Vanuytsel [I7] & 2001 & 53 & 36 & $46 \%$ at 3 years \\
\hline Chawla [18] & 2002 & 54 & 45 & $35 \%$ at 5 years \\
\hline De la Taille [19] & 2002 & 52 & 28 & $51 \%$ at 3 years \\
\hline Do [20] & 2002 & 73 & 87 & $45 \%$ at 10 years \\
\hline Kalapurakal [2I] & 2002 & 41 & 31 & $57 \%$ at 5 years \\
\hline Song [22] & 2002 & 61 & 36 & $39 \%$ at 4 years \\
\hline Liauw [23] & 2003 & 51 & 46 & $56 \%$ at 3 years \\
\hline Peyromaure [24] & 2003 & 62 & 44 & $42 \%$ at 5 years \\
\hline Taylor [25] & 2003 & 44 & 35 & $66 \%$ at 5 years \\
\hline Mc Donald [26] & 2004 & 102 & 50 & $38 \%$ at 5 years \\
\hline Stephenson [27] & 2004 & 501 & 45 & $50 \%$ at 45 months \\
\hline Patel [28] & 2005 & 48 & 16 & $62.5 \%$ at 16 months \\
\hline Buskirk [29] & 2006 & 368 & 60 & $46 \%$ at 5 years \\
\hline Neuhof [30] & 2007 & 171 & 39 & $35 \%$ at 5 years \\
\hline Stockdale [3I] & 2007 & 32 & 30 & $56 \%$ at 30 months \\
\hline Current study & - & 59 & 38 & $56 \%$ at 3 years \\
\hline
\end{tabular}


Poorer prognoses, in terms of bDFS after RT, were previously associated with mainly: higher preRT PSA values, high-grade disease, and seminal vesicle involvement [1327]. Indeed, for our 59 patients, preRT PSA was associated with biochemical relapse after RT.

High preRT PSA was associated with poor biochemical control after RT regardless of the biochemical definition used. This observation is consistent with the previously reported finding that preRT PSA was the most frequently selected factor predictive of bDFS [5-31]. Those authors described poorer prognoses associated with higher PSA values before RT using thresholds ranging from 0.4 to 2 $\mathrm{ng} / \mathrm{ml}$. An ASTRO consensus panel recommended that RT be delivered before the PSA level reaches $1.5 \mathrm{ng} / \mathrm{ml}$ [32]. For our patients with a preRT PSA $<1 \mathrm{ng} / \mathrm{ml}$, the 3 -year bDFS was significantly higher than for those with a PSA $\geq 1$ $\mathrm{ng} / \mathrm{ml}$ (70 vs 30\% respectively). We analyzed 3 -year bDFS as a function of different preRT PSA thresholds: rates declined as PSA concentrations increased from $<0.5$ $(66.4 \%)$ to $\geq 2 \mathrm{ng} / \mathrm{ml}$ (only $33 \%$ ). These significantly different rates $(p=0.008)$ are strong arguments supporting early treatment after biochemical relapse. We think that, in the setting of RT, the earlier the better. When biochemical failure is confirmed, and a sufficient number of factors suggestive of local relapse are present, patients should be irradiated without waiting for PSA to reach 1 or $1.5 \mathrm{ng} / \mathrm{ml}$.

Recently, the randomized EORTC 22911 study demonstrated significant improvement for adjuvant RT vs salvage RT in terms of bDFS and clinical local control at 5 years but not for overall survival [33]. Similarly, adjuvant RT significantly increased bDFS vs observation in the ARO 96-02 and the SWOG 8794 studies [34,35]. But adjuvant RT based only on unfavorable histological prognostic features (positive surgical margins, seminal vesicle involvement or extra capsular effraction) would expose some of these patients to over treatment with the risk of incontinence and urethral stricture resulting from the accumulation of the two treatments. Indeed $40-50 \%$ of the patients with positive surgical margins would develop biochemical relapses at 5-years [36,37]. To conclude definitively, we should compare adjuvant radiotherapy vs early salvage radiotherapy: GETUG and RADICALS ongoing trials will try to answer to this question.

Gleason score and high grade prostate cancer was associated with poor biochemical outcome in previous reported studies [19-30]. However, we did not find any significant bDFS difference for patients with a low $(\leq 6)$ or high $(\geq 7)$ Gleason scores. Seminal vesicle involvement or margin status was also previously associated with poorer outcome.
In this study, we did not observe any difference in terms of incontinence (grade $\geq 2$ ) according to EPIC score or rectal toxicity (grade $\geq 2$ ) between salvage 3D and 2D RT. Urinary tract toxicities (stricture, hematuria) were also similar for the two techniques, with very low frequencies in both groups which is consistent with the MSKCC experience, in which adjuvant/salvage 3D RT was associated with 5\% grade $\geq 2$ toxicity [38].

\section{Conclusion}

Salvage RT is an effective treatment after radical prostatectomy. bDFS 3- and 5-years after salvage RT were 56\% and $41 \%$, respectively. RT was well tolerated in terms of urinary toxicity, especially with 3D RT. PreRT PSA was the most powerful prognostic of bDFS before RT delivery and surpassed all other factors evaluated. To increase its efficacy, RT should be given earlier after biochemical relapse, ideally when preRT PSA $<1 \mathrm{ng} / \mathrm{ml}$, to obtain the best biochemical control.

\section{Competing interests}

The author(s) declare that they have no competing interests.

\section{Authors' contributions}

LQ wrote the manuscript, collected and interpreted the data, performed the analysis and reviewed the literature. PMA performed the surgical treatment and revised the manuscript.

VR performed the surgical treatment and revised the manuscript. CM performed the radiotherapy treatment and revised the manuscript. FD performed the surgical treatment and revised the manuscript. $\mathrm{CH}$ was involved in the writing of the manuscript, performed the statistical analysis and revised the manuscript. All authors read and approved the final manuscript.

\section{Acknowledgements}

The authors are indebted to Janet Jacobson for editing the manuscript.

\section{References}

I. Boyle P, Ferlay J: Cancer incidence and mortality in Europe, 2004. Ann Oncol 2005, 16:48I-488.

2. Ohori M, Goad JR, Wheeler TM, Eastham JA, Thompson TC, Scardino PT: Can radical prostatectomy alter the progression of poorly differentiated prostate cancer? J Urol 1994, I52:1843-1849.

3. Pound CR, Partin AW, Epstein JI, Walsh PC: Prostate-specific antigen after anatomic radical retropubic prostatectomy. Patterns of recurrence and cancer control. Urol Clin North Am 1997, 24:395-406.

4. Pound CR, Partin AW, Eisenberger MA, Chan DW, Pearson JD, Walsh PC: Natural history of progression after PSA elevation following radical prostatectomy. JAMA 1999, 28 I:I59I-1597.

5. Cadeddu JA, Partin AW, DeWeese TL, Walsh PC: Long-term results of radiation therapy for prostate cancer recurrence following radical prostatectomy. J Urol 1998, 159:173-7.

6. Taylor N, Kelly JF, Kuban DA, Babaian RJ, Pisters LL, Pollack A: Adjuvant and salvage radiotherapy after radical prostatectomy for prostate cancer. Int J Radiat Oncol Biol Phys 2003, 56:755-763. 
7. Anscher MS: Salvage radiotherapy for recurrent prostate cancer: the earlier the better. JAMA 2004, 29 I: |380-I382.

8. Schmid HP, McNeal JE, Stamey TA: Observations on the doubling time of prostate cancer. The use of serial prostate-specific antigen in patients with untreated disease as a measure of increasing cancer volume. Cancer 1993, 7 I:203 I-2040.

9. Cox JD, Stetz J, Pajak TF: Toxicity criteria of the Radiation Therapy Oncology Group (RTOG) and the European Organization for Research and Treatment of Cancer (EORTC). Int J Radiat Oncol Biol Phys 1995, 3 I: I34 |-I346.

10. Wei JT, Dunn RL, Litwin MS, Sandler HM, Sanda MG: Development and validation of the expanded prostate cancer index composite (EPIC) for comprehensive assessment of healthrelated quality of life in men with prostate cancer. Urology 2000, 56:899-905.

II. Anscher MS, Clough R, Dodge R: Radiotherapy for a rising prostate-specific antigen after radical prostatectomy: the first 10 years. Int J Radiat Oncol Biol Phys 2000, 48:369-375.

12. Peschel RE, Robnett TJ, Hesse D, King CR, Ennis RD, Schiff PB, Wilson LD: PSA based review of adjuvant and salvage radiation therapy vs. observation in postoperative prostate cancer patients. Int J Cancer 2000, 90:29-36.

13. Pisansky TM, Kozelsky TF, Myers RP, Hillman DW, Blute ML, Buskirk SJ, Cheville JC, Ferrigni RG, Schild SE: Radiotherapy for isolated serum prostate specific antigen elevation after prostatectomy for prostate cancer. J Urol 2000, 163:845-850

14. Catton C, Gospodarowicz M, Warde P, Panzarella T, Catton P, McLean M, Milosevic M: Adjuvant and salvage radiation therapy after radical prostatectomy for adenocarcinoma of the prostate. Radiother Oncol 200I, 59:5I-60.

15. Koppie TM, Grossfeld GD, Nudell DM, Weinberg VK, Carroll PR: Is anastomotic biopsy necessary before radiotherapy after radical prostatectomy? J Urol 200I, I66: III-II5.

16. Leventis AK, Shariat SF, Kattan MW, Butler EB, Wheeler TM, Slawin $K M$ : Prediction of response to salvage radiation therapy in patients with prostate cancer recurrence after radical prostatectomy. I Clin Oncol 200I, 19:1030-1039.

17. Vanuytsel L, Janssens G, Van Poppel H, Rijnders A, Baert L: Radiotherapy for PSA recurrence after radical prostatectomy. Eur Urol 200I, 39:425-429.

18. Chawla AK, Thakral HK, Zietman AL, Shipley WU: Salvage radiotherapy after radical prostatectomy for prostate adenocarcinoma: analysis of efficacy and prognostic factors. Urology 2002, 59:726-731.

19. De la Taille A, Flam T, Thiounn N, Pontvert D, Saighi D, Zerbib M, Debre B: Predictive factors of radiation therapy for patients with prostate specific antigen recurrence after radical prostatectomy. BJU Int 2002, 90:887-892.

20. Do LV, Do TM, Smith R, Parker RG: Postoperative radiotherapy for carcinoma of the prostate: impact on both local contro and distant disease-free survival. Am / Clin Oncol 2002, 25: I-8.

21. Kalapurakal JA, Huang CF, Neriamparampil MM, Small WJ Jr, Pins MR, Mittal BB, Campbell SC, Grayhack JT, Shetty RM: Biochemical disease-free survival following adjuvant and salvage irradiation after radical prostatectomy. Int J Radiat Oncol Biol Phys 2002, 54: 1047-1054.

22. Song DY, Thompson TL, Ramakrishnan V, Harrison R, Bhavsar N, Onaodowan O, De Weese TL: Salvage radiotherapy for rising or persistent PSA after radical prostatectomy. Urology 2002, 28I:28I-287.

23. Liauw SL, Webster WS, Pistenmaa DA, Roehrborn CG: Salvage radiotherapy for biochemical failure of radical prostatectomy: a single-institution experience. Urology 2003, 61:1204-1210

24. Peyromaure M, Allouch M, Eschwege F, Verpillat P, Debre B, Zerbib $M$ : Salvage radiotherapy for biochemical recurrence after radical prostatectomy: a study of $\mathbf{6 2}$ patients. Urology 2003, 62:503-507.

25. Taylor N, Kelly JF, Kuban DA, Babaian RJ, Pisters LL, Pollack A: Adjuvant and salvage radiotherapy after radical prostatectomy for prostate cancer. Int J Radiat Oncol Biol Phys 2003, 56:755-763.

26. MacDonald OK, Schild SE, Vora S, Andrews PE, Ferrigni RG, Novicki $D E$, Swanson SK, Wong WW: Salvage radiotherapy for men with isolated rising PSA or locally palpable recurrence after radical prostatectomy: do outcomes differ? Urology 2004 64:760-764.
27. Stephenson AJ, Shariat SF, Zelefsky MJ, Kattan MW, Butler EB, Teh BS, Klein EA, Kupelian PA, Roehrborn CG, Pistenmaa DA, Pacholke HD, Liauw SL, Katz MS, Leibel SA, Scardino PT, Slawin KM: Salvage radiotherapy for recurrent prostate cancer after radical prostatectomy. JAMA 2004, 29 I: I 325-I 332.

28. Patel $\mathrm{R}$, Lepor $\mathrm{H}$, Thiel $\mathrm{R}$, Taneja S: Prostate-specific antigen velocity accurately predicts response to salvage radiotherapy in men with biochemical relapse after radical prostatectomy. Urology 2005, 65:942-946.

29. Buskirk S, Pisansky T, Schild S, Macdonald O, Wehle M, TF K, Collie A, Ferrigni R, Myers R, Prussak K, Heckman M, Crook J, Parker A, Igel $T$ : Salvage radiotherapy for isolated prostate specific antigen increase after radical prostatectomy: evaluation of prognostic factors and creation of a prognostic scoring system. J Urol 2006, I76:985-990.

30. Neuhof DH, Bischof T, Sroka-Perez M, Hohenfellner G, Debus MJ: Long-term results and predictive factors of three-dimensional conformal salvage radiotherapy for biochemical relapse after prostatectomy. Int J Radiat Oncol Biol Phys 2007, 67:14III-14I7.

3I. Stockdale A, Vakkalanka B, Fahmy A, Desai K, Blacklock A: Management of biochemical failure following radical prostatectomy: salvage radiotherapy - a case series. Prostate Cancer Prostatic Dis 2007, 10:205-209.

32. Cox JD, Gallagher MJ, Hammond EH, Kaplan RS, Schellhammer PF: Consensus statements on radiation therapy of prostate cancer: guidelines for prostate re-biopsy after radiation and for radiation therapy with rising prostate-specific antigen levels after radical prostatectomy. American Society for Therapeutic Radiology and Oncology Consensus Panel. J Clin Oncol 1999, I7:II55-1163.

33. Bolla M, Van Poppel H, Collette L, van Cangh P, Vekemans K, Da Pozzo L, de Reijke TM, Verbaeys A, Bosset JF, van Velthoven R, Marechal JM, Scalliet P, Haustermans K, Pierart M: Postoperative radiotherapy after radical prostatectomy: a randomised controlled trial (EORTC trial 229II). Lancet 2005, 366:572-578.

34. Wiegel T, Botcke D, Willich N, Piechota H, Souchon R, Stoeckle MC, Ruebe A, Hinkelbein W, Miller K: Phase III results of adjuvant radiotherapy (RT) versus "wait and see" (WS) in patients with PT3 prostate cancer following radical prostatectomy (RP)(ARO 96-02/AUO AP 09/95). I Clin Oncol (Meeting Abstracts) 2005, 23:45I3

35. Thompson IM Jr, Tangen CM, Paradelo J, Lucia MS, Miller G, Troyer D, Messing E, Forman J, Chin J, Swanson G, Canby-Hagino E, Crawford ED: Adjuvant radiotherapy for pathologically advanced prostate cancer: a randomized clinical trial. JAMA 2006, 296:2329-2335

36. Paulson DF: Impact of radical prostatectomy in the management of clinically localized disease. J Urol 1994, I 52: I 826- I830.

37. Kupelian PA, Katcher J, Levin HS, Klein EA: Stage TI-2 prostate cancer: a multivariate analysis of factors affecting biochemical and clinical failures after radical prostatectomy. Int / Radiat Oncol Biol Phys 1997, 37: 1043-1052.

38. Zelefsky MJ, Aschkenasy E, Kelsen S, Leibel SA: Tolerance and early outcome results of postprostatectomy three-dimensional conformal radiotherapy. Int J Radiat Oncol Biol Phys 1997, 39:327-333.

\section{Pre-publication history}

The pre-publication history for this paper can be accessed here:

http://www.biomedcentral.com/1471-2407/8/26/prepub 